\title{
A Rapid and Simple Spectrophotometric Determination of Traces of Chromium (VI) in Waste Water Samples and in Soil samples by using 2-Hydroxy, 3-Methoxy Benzaldehyde Thiosemicarbazone (HMBATSC)
}

\author{
I. Sreevani ${ }^{\mathrm{a}}$, P. Raveendra Reddy*b, V. Krishna Reddy ${ }^{\mathrm{b}}$ \\ ${ }^{a}$ Department of Chemistry, K.S.R.M. College of Engineering, Kadapa, A.P., India. \\ ${ }^{b}$ Department of Chemistry, S.K. University, Anantapur, A.P., India
}

\begin{abstract}
A rapid and simple Spectrophotmetric method has been developed for the determination of microgram amount of Chromium (VI) in aqueous dimethyl formamide (DMF). Chromium (VI) forms a yellowish green coloured M:L complex with 2-hydroxy-3-methoxy benzaldehyde thiosemicarbazone in the acidic buffer medium $(p H=6.0)$ at room temperature. The complex shows maximum absorption at 385nm. Beer's law is obeyed in the range 0.260 to $2.60 \mu \mathrm{gmL}^{-1}$. The sensitivity of the proposed method has been derived from its molar absorptivity value $\left(1.202 \times 10^{3}\right.$ lit.mol $\left.{ }^{-1} \mathrm{~cm}^{-1}\right)$, detection limit $\left(0.014 \mu \mathrm{g} \mathrm{mL}^{-1}\right)$ and determination limit $\left(0.041 \mu \mathrm{g} \mathrm{mL}^{-1}\right)$, correlation coefficient (0.9999) and relative standard deviation $(0.32 \%)$ confirm the best suitability of the proposed method for the determination of chromium (VI). The effect of foreign ions on the determination was studied. A second order derivative spectrophotometric method for the determination of chromium (VI) has also been proposed. This method was applied for the determination of chromium (VI) concentration in samples of circulating industrial waste water, soil samples and in standard steel samples.
\end{abstract}

Keywords: Chromium (VI), HMBATSC, DMF, Direct spectrophotometry and Derivative spectrophotometry.

\section{Introduction}

Hexavalent chromium is recognized as a human carcinogen via inhalation [1]. Chromic inhalation of hexavalent chromium compounds increases risk of lung cancer. According to some researches [1], the damage is caused by hydroxyl radicals, produced during reoxidation of pentavalent chromium by hydrogen peroxide molecules present in the cell. Zinc chromate is the strongest carcinogen of the chromates used in industry. Due to its high toxic nature, the determination of trace amounts of chromium (VI) is of great importance. Only handful of methods is reported during the last 50 years. Of these, most of the methods are less sensitive and less selective. Hence, there is a great need for the development of some more sensitive, selective and simple methods for the effective determination of microgram amounts of chromium. Spectrophotometric methods were preferred because they are cheaper and easier to handle with comparable sensitivity. Among various organic reagents containing sulphur and nitrogen as donor atoms, thiosemicarbazones occupy a unique place. Thosemicarbazones [2-8] were the important classes of reagents widely employed for the sepectrophotometric determination of metal ions.

In the present paper 2-hgydroxy-3-methoxy benzaldehyde thiosemicarbazone used as new reagent, and structure of HMBATSC as follows in figure 1.

A simple, rapid, selective and sensitive method was reported for the spectrophotometic determination of trace amounts of chromium (VI) by complexing it with 2-hydroxy-3-methoxy benzaldehyde thiosemicarbazone (HMBATSC). The reagent forms a yellowish green coloured complex with chromium (VI) at pH 6.0 which is fairly stable. Hence, a systematic study has been made to develop a direct and derivative spectrophotometric method for the determination of chromium (VI) in industrial waste water, soil samples and in standard steel samples.

\section{Reagents and Solutions}

\section{Experimental}

All the chemicals were of analytical grade (AR BDH, ERE Merck). Double distilled water was used throughout. A standard $(0.01 \mathrm{M})$ chromium (VI) solution was prepared by dissolving $0.194 \mathrm{gr}$ of potassium chromate (AR BDH) in $100 \mathrm{ml}$ of distilled water. HMBATSC solution $(0.01 \mathrm{M})$ was prepared by dissolving $0.225 \mathrm{gr}$ of HMBATSC in small amount of dimethyl formamide (DMF) in $100 \mathrm{ml}$ of volumetric flask and made up to the mark with DMF. The stock solution is suitably diluted to get the required concentration wherever necessary. Buffer solutions were prepared by mixing $0.2 \mathrm{M}$ sodium acetate, and $0.2 \mathrm{M}$ acetic acid $(\mathrm{pH} 6.0)$. Daily all the solutions were prepared fresh. 


\section{Apparatus}

A shimadzu UV-visible spectrophotometer (model UV-160A) fitted with $1 \mathrm{~cm}$ quartz cells, measuring wavelength range $200-1100 \mathrm{~nm}$ and slit width of $2 \mathrm{~mm}$ was used to measure abosrbances of all analytical species. All spectral measurements were performed using the blank solution as a reference. Measurement of $\mathrm{pH}$ was carried out on a Phillips digital pH meter (model LI 613).

\section{Procedure}

\section{Direct Spectrophotometry}

In each of a set of different $10 \mathrm{ml}$ volumetric flasks, $5 \mathrm{ml}$ of buffer solutions ( $\mathrm{pH} 6.0$ ), and $1 \mathrm{ml}$ of HMBATSC $\left(1 \mathrm{X} 10^{-2} \mathrm{M}\right)$ were taken and various values of chromium $(\mathrm{VI})\left(1 \mathrm{X} 10^{-3} \mathrm{M}\right)$ solution were added. The resultant solutions were made up to the mark with distilled water. The absorbance was measured at $385 \mathrm{~nm}$ against the reagent blank. The calibration plot was prepared by plotting the absorbance against the amount of chromium (VI).

\section{Second Derivative Spectrophotometry}

Second order derivate spectra were recorded for the above solutions with a scan speed of nearly $2400 \mathrm{~nm}$ $\min ^{-1}$; slit width of $1 \mathrm{~nm}$ with nine degrees of freedom, in the wavelength range $350-600 \mathrm{~nm}$. The derivative amplitudes were measured at wavelength of $408 \mathrm{~nm}$ and plotted against amount of chromium (VI) to obtain the calibration plot.

\section{Results and Discussion}

The absorption spectra were recorded in wavelength region $380-500 \mathrm{~nm}$ for the yellowish green coloured [Cr(VI)-HMBATSC] complex against the reagent blank and HMBATSC against buffer blank as presented in figure 2 .

From the spectrum it can be seen that there is a peak with maximum absorption at $385 \mathrm{~nm}$. The absorption for the reagent blank is considerably less at $385 \mathrm{~nm}$. The analytical studies were carried out at $385 \mathrm{~nm}$, as the maximum absorbance for the complex and the minimum absorbance of the blank was at this wavelength. [Cr(VI)-HMBATSC] yellowish green coloured complex with maximum and constant absorbance in the $\mathrm{pH}$ region 5.5 to 6.5. Further studies therefore, were carried out at $\mathrm{pH}$ 6.0. A minimum of 10 fold excess of reagent is necessary to obtain maximum sensitivity for the colour reaction between $\mathrm{Cr}$ (VI) and HMBATSC.

Variable amounts of $\mathrm{Cr}(\mathrm{VI})$ in the range 0.260 to $2.60 \mu \mathrm{g} \mathrm{mL}^{-1}$, taken in different $10 \mathrm{ml}$ volumetric flasks, were treated with optimum amount of HMBATSC solution and buffer solution of $\mathrm{pH}$ 6.0. The absorbance of the resultant solution was measured at $385 \mathrm{~nm}$ and plotted against the amount of $\mathrm{Cr}(\mathrm{VI})$. A straight line with a slope of 1.189 passing through the absorbance values was obtained as shown in Figure 3.

This shows that Beer's law is obeyed in the concentration range 0.26 to $2.6 \mu \mathrm{g} \mathrm{mL}^{-1}$ of $\mathrm{Cr}(\mathrm{VII})$. The sensitivity of the proposed method has been derived from its molar absorptivity value $\left(\in=1.20 \times 10^{3} 1\right.$ lit. $\left.\mathrm{mol}^{-1} \mathrm{~cm}^{-1}\right)$, detection limit $\left(0.014 \mu \mathrm{g} \mathrm{mL}^{-1}\right)$ and determination limit $\left(0.041 \mu \mathrm{g} \mathrm{mL}^{-1}\right)$, correlation coefficient $(0.9999)$ and relative standard deviation $(0.32 \%)$ confirm the best suitability of the proposed method for the determination of $\mathrm{Cr}(\mathrm{VI})$

The effect of various anions and cations normally associated with $\mathrm{Cr}(\mathrm{VI})$ on the absorbance of the experimental solution was studied. The tolerance limits of the tested foreign ions, which brings about a change in the absorbance by $\pm 2 \%$ were calculated and presented in table 1 . Almost all the tested anions possess high tolerance levels ( $>75$ fold excess).

Among the metal ions, most of them are tolerable and is more than 20 fold excess. Ru(III) was tolerable upto 15 fold excess. Mo(VI), $\mathrm{Cu}(\mathrm{II}), \mathrm{Mn}(\mathrm{II}), \mathrm{V}(\mathrm{V}), \mathrm{Fe}(\mathrm{II}), \mathrm{Fe}(\mathrm{III}), \mathrm{Pd}(\mathrm{II}), \mathrm{In}(\mathrm{III})$ interfere seriously.

The stoichiometry of [Cr(VI)-HMBATSC] complex solution was determined by Job's continuous variation method and mole ratio method obtained as 1:1 (M:L) and the possible geometry of chromium (VI) complexes and the coordination sites of the ligand suggest the following possible structure for $\mathrm{Cr}(\mathrm{VI})$ and HMBATSC complex shown in figure 4.

The formation constant of the soluble complex was calculated from the results obtained in Job's method as $6.95 \times 10^{4}$.

\section{Applications}

The usefulness of the proposed method was tested by determining Chromium (VI) concentration in samples of circulating industrial waste water[9] and in soil samples[10], previously certified by atomic absorption spectrometry. Recovery tests for the analyzed samples were satisfactory (about $98 \%$ to $101 \%$ ) with relative error of \pm 0.1 to 1.5 (Table 2 ).

\section{Determination of Chromium(VI) in Industrial Waste Water samples}

The proposed method possesses a low detection limit satisfactory for given application, high precision and simple instrumentation, and can be applied for determination of chromium (VI) in industrial and waste waters polluted with chromium. The results obtain is shown in the table 2 . 


\section{Determination of Chromium in Soil samples}

A known amount of (1g) air dried homogenized soil samples, spiked with known amounts of chromium (VI) was taken and then fused with $5 \mathrm{~g}$ anhydrous sodium carbonate in a nickel crucible and evaporated to dryness after the addition of $25 \mathrm{ml}$ of water. The dried material was dissolved in water, filtered through Whatman filter paper (No.40) in to $25 \mathrm{~mL}$ calibrated flask and neutralized with dilute ammonia. It was then diluted to a known volume with water. An aliquot of this sample solution was analyzed for chromium (VI). The obtained results were tabulated in table 3 .

\section{Second Order derivative Spectrophotometry}

In order to improve the sensitivity and selectivity of the direct spectrophotometric method proposed, the absorbance data was derivatized twice and plotted against the wavelength which gave the 2nd order derivative curve.

\section{Derivative Curve}

0.15-4.0 $\mu \mathrm{g}$ of $\mathrm{Cr}(\mathrm{VI})$ were treated with suitable amounts of HMBATSC in buffer solutions of $\mathrm{pH} 6.0$ and made up to $10 \mathrm{ml}$ with distilled water. The 2 nd derivative curves were recorded in the wavelength region $350-600 \mathrm{~nm}$. In the second derivative curve, maximum amplitude was observed at 408nm (Figure 5). Determination of chromium (VI) was carried out by measuring the derivative amplitudes at $408 \mathrm{~nm}$.

Calibration plot drawn between the amount of $\mathrm{Cr}(\mathrm{VI})$ and measured derivative amplitudes for the derivative spectrum is shown in the figure 6.

The determinable range for the derivative spectra was $0.13-3.92 \mu \mathrm{g} \mathrm{mL}^{-1}$. The analytical and statistical results of the direct and derivative methods were presented in the table 4 . The results show that the derivative method is more sensitive and possess larger determinable range than the direct method.

\section{Effect of diverse ions}

When compared to the zero order method, the tolerance limits of large number of ions which were very low in the zero order method were found to be much higher in the derivative method. This shows the greater selectivity of the derivative method when compared to zero order method. The results obtained in these studies are presented in the table 5 .

\section{Applications}

The proposed spectrophotometric method was used for the analysis of standard steel samples[11]. The results are shown in table 6 .

\section{Conclusions}

The present method for the spectrophotometric determination of chromium (VI) in industrial waste water soil samples and in standard steel samples were rapid simple selective and sensitive statistical analysis of the results indicates the methods yield good values, it was clear that second order derivative method was more sensitive than the direct method.

\section{References}

[1] IARC [1990] (1990-11-05) Volume 49: Chromium, Nickel and Welding, ISB 92-832-1249-5.

[2] Singh R,B. Garg,, B.S., and Singh, R.P., "Analytical Applications of thiosemicarbazones and semicarbazones: a review", Talanta, Vol.25, No.11-12, pp.619-632, 1978.

[3] Reddy, K.H., and Reddy, D.V., Q.Chem., Rev, Vol.1, p.47, 1985.

[4] Garg, B.S., and Jain, V.K., "Analytical Applications of thiosemicarbazones and semicarbazones", Micro-chemical Journal, Vol.38, No.2, pp.144-169, 1988.

[5] Ramanjaneyulu, G., Reddy, P.R., Reddy, V.K., and Reddy, T.S., "Spectrophotometric determination of iron in trace amount using 5 bromo-salicyladehyde thiosemicarbazone", Indian Journal of Chemistry-Section A, Inorganic, Physical, Theoretical and Analytical Chemistry, Vol.41, No.7, pp.1436-1437, 2002.

[6] Reddy, K.H., Prasad, N.B.L., and Reddy, T.S., "Analytical properties of 1-phenyl-1,2-propanedione-2-oxime thiosemicarbazone: simultaneous spectrophoto-metric determination of coppoer(II) and Nickel (II) in edible oils and seeds", Talanta, Vol.59, No.3, pp.425-433, 2003.

[7] Ramanjaneyulu, G., Reddy, P.R., Reddy, V.K., and Reddy, T.S., "Direct and Derivative spectrophotometric determination of cobalt with 5-bromosalicyladehyde-thiosemicarbazone", Journal of the Indian Chemical Society, Vol.80, No.8, pp.773-776, 2003.

[8] Reddy, B.K., Reddy, K.J., Kumar, J.R., Kumar, A.K., and Reddy, A.V., "High sensitive extractive spectro-photometric determination of palladium(II) in synthetic mixtures and hydrogenation catalysts using benzildi-thiosemicarbazone", Analytical Sciences, Vol.20, No.6, p.925, 2004.

[9] Angetina M. Stoyanova, Turkish Journal of Biochemistry, Vol..29(2), 2004, pp.204 -207.

[10] Narayana, B. Tomcherian, J. Broaz Chem. Soc., Vol.16, No.2, 2005, pp.197-201.

[11] Milliam B. Ferug and Gpordon A. Pareker, Freesenius Z., Anal. Chem., 304, 1980, pp.382-384. 


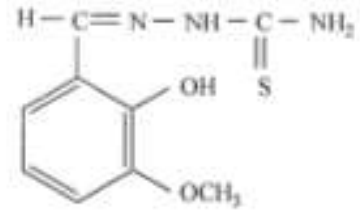

Figure 1: Structure of HMBATSC

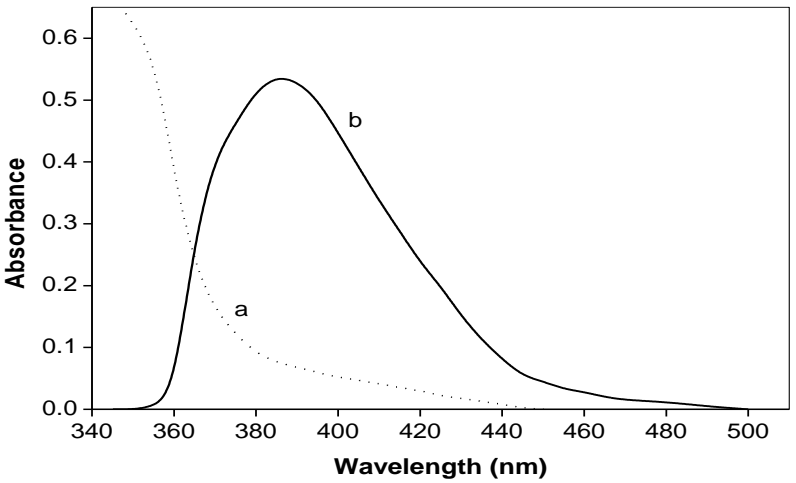

Figure 2: Absorption spectra of

(a) HMBATSC Vs Buffer Blank

(b) $[\mathrm{Cr}(\mathrm{VI})$ - HMBATSC] Vs Reagent blank



Figure 3: Calibration plot for $\mathrm{Cr}(\mathrm{VI})[\mathrm{HMBATSC}]=1 \times 10^{-3}$; Wavelength $=385 \mathrm{~nm}, \mathrm{pH}=6.0$

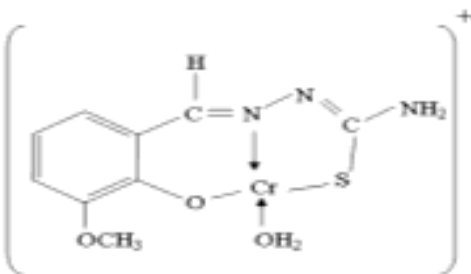

Figure 4: Structure of Cr(VI) - HMBATSC Complex

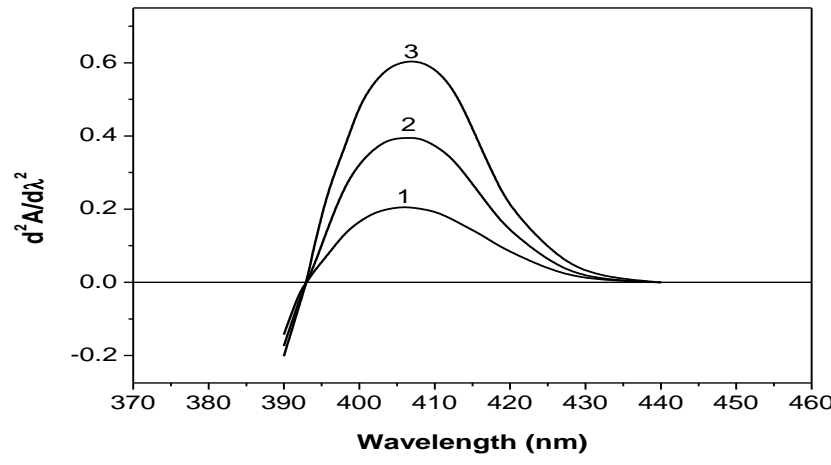

Figure 5: Second Derivative Spectra of

Cr(VI) - HMBATSC vs Reagent blank

$[\mathrm{Cr}(\mathrm{VI})]\left(\mu \mathrm{g} \mathrm{mL}^{-1}\right)=(1) 0.65 ;(2) 1.30,(3) 1.95$ 


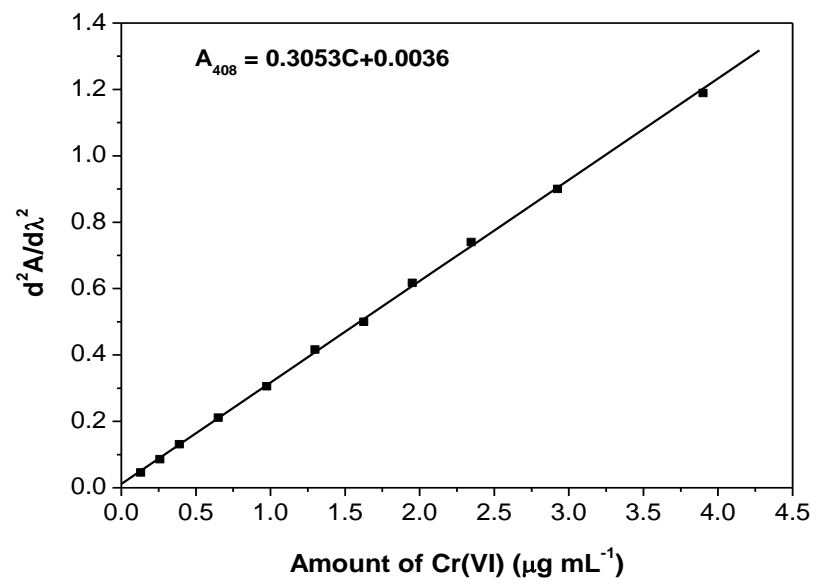

Figure 6: Calibration plot for $\mathrm{Cr}(\mathrm{VI})$

$\left[\right.$ HMBATSC] $=1 \times 10^{-3}$; Wavelength $=408 \mathrm{~nm} \mathrm{pH}=6.0$

Table 1 : Tolerance limits of diverse ions

Amount of $(\mathrm{Cr}(\mathrm{VI}))$ taken $=0.26 \mu \mathrm{g} \mathrm{mL}^{-1}, \mathrm{pH}=6.0$

\begin{tabular}{|c|c|c|c|}
\hline $\begin{array}{l}\text { Diverse Ion } \\
\text { (anion) }\end{array}$ & $\begin{array}{l}\text { Tolerance Limit } \\
\qquad\left(\mu \mathrm{g} \mathrm{mL}^{-1}\right)\end{array}$ & $\begin{array}{c}\text { Diverse Ion } \\
\text { (Cation) }\end{array}$ & $\begin{array}{l}\text { Tolerance Limit } \\
\quad\left(\mu \mathrm{g} \mathrm{mL}^{-1}\right)\end{array}$ \\
\hline Thiosulphate & 4300 & $\mathrm{Th}(\mathrm{IV})$ & 895 \\
\hline Thio Urea & 2920 & $\mathrm{Bi}(\mathrm{III})$ & 805 \\
\hline Thiocyanate & 2230 & $\mathrm{~Pb}(\mathrm{II})$ & 800 \\
\hline Oxalate & 2115 & Tl(III) & 790 \\
\hline Phosphate & 1405 & $\mathrm{Au}(\mathrm{III})$ & 760 \\
\hline Citrate & 655 & $\mathrm{Ir}(\mathrm{III})$ & 740 \\
\hline Tartrate & 570 & $\mathrm{~W}(\mathrm{VI})$ & 710 \\
\hline Sulphate & 570 & $\mathrm{Te}(\mathrm{IV})$ & 490 \\
\hline Iodide & 490 & $\mathrm{Sn}(\mathrm{IV})$ & 460 \\
\hline Carbonate & 450 & U(VI) & 455 \\
\hline EDTA & 425 & Y(III) & 340 \\
\hline Ascorbic acid & 250 & $\mathrm{Zr}(\mathrm{IV})$ & 330 \\
\hline Nitrate & 240 & $\mathrm{Se}(\mathrm{IV})$ & 300 \\
\hline Chloride & 135 & $\operatorname{Ag}(\mathrm{I})$ & 240 \\
\hline Flouride & \multirow[t]{17}{*}{75} & $\mathrm{Ce}(\mathrm{IV})$ & 125 \\
\hline & & $\mathrm{Al}(\mathrm{III})$ & 105 \\
\hline & & $\mathrm{Hg}$ (II) & 80 \\
\hline & & $\mathrm{Cd}(\mathrm{II})$ & 60 \\
\hline & & $\mathrm{Co}$ (II) & 55 \\
\hline & & $\mathrm{Ga}$ (III) & 25 \\
\hline & & $\mathrm{Zn}$ (II) & 25 \\
\hline & & $\mathrm{Ni}(\mathrm{II})$ & 20 \\
\hline & & $\mathrm{Ru}(\mathrm{III})$ & 15 \\
\hline & & $\mathrm{Mo}(\mathrm{VI})$ & 4 \\
\hline & & $\mathrm{Cu}(\mathrm{II})$ & 3 \\
\hline & & $\mathrm{Mn}$ (II) & 2 \\
\hline & & $\mathrm{V}(\mathrm{V})$ & 2 \\
\hline & & $\mathrm{Fe}(\mathrm{II})$ & 1 \\
\hline & & $\mathrm{Fe}$ (III) & $<1$ \\
\hline & & $\mathrm{Pd}(\mathrm{II})$ & $<1$ \\
\hline & & $\operatorname{In}(\mathrm{III})$ & $<1$ \\
\hline
\end{tabular}

Table 2: Determination of chromium (VI) in waste water samples

\begin{tabular}{|c|c|c|c|c|}
\hline \multicolumn{2}{|c|}{ Chromium (VI) concentration $\mu \mathbf{g ~ m L}^{-1}$} & $\begin{array}{c}\text { Relative error } \\
(\boldsymbol{\%})\end{array}$ & $\begin{array}{c}\text { Recovery } \\
(\boldsymbol{\%})\end{array}$ \\
\hline Sample (AAS) & Added & Found $^{*}$ & +1.50 & 98.5 \\
\hline \multirow{3}{*}{13.6} & - & 13.4 & +1.30 & 98.7 \\
\cline { 2 - 5 } & 10.0 & 23.3 & -0.70 & 100.6 \\
\cline { 2 - 5 } & 15.0 & 28.8 & & \\
\hline
\end{tabular}




\begin{tabular}{|c|c|c|c|c|}
\hline \multirow{3}{*}{40.6} & - & 40.5 & +0.25 & 99.7 \\
\cline { 2 - 5 } & 20.0 & 60.4 & +0.33 & 99.6 \\
\cline { 2 - 5 } & 25.0 & 65.7 & -0.15 & 100.1 \\
\hline \multirow{3}{*}{68.8} & - & 68.9 & -0.15 & 100.1 \\
\cline { 2 - 5 } & 30.0 & 98.5 & +0.30 & 99.7 \\
\cline { 2 - 5 } & 35.0 & 103.4 & +0.40 & 99.6 \\
\hline
\end{tabular}

* Average of five determinations

Table 4: Analytical characteristics of [Cr(VI)-HMBATSC]

\begin{tabular}{|l|c|c|}
\hline \multicolumn{1}{|c|}{ Parameter } & Direct method & $\begin{array}{c}\text { Second derivative } \\
\text { method }\end{array}$ \\
\hline Analytical wavelength $(\mathrm{nm})$ & 385 & 408 \\
\hline Beer's law range $\left(\mu \mathrm{g} \mathrm{mL}^{-1}\right)$ & $0.26-2.6$ & $0.13-3.92$ \\
\hline Molar absorptivity $\left(\mathrm{L} \mathrm{mol}^{-1} \mathrm{~cm}^{-1}\right)$ & $1.20 \times 10^{3}$ & - \\
\hline Sandell's sensitivity $\left(\mu \mathrm{g} \mathrm{cm}^{-2}\right)$ & 0.0433 & - \\
\hline Angular coefficient $(\mathrm{m})$ & 1.189 & 0.305 \\
\hline Y intercept $(\mathrm{b})$ & 0.0018 & 0.0036 \\
\hline Correlation coefficient $(\gamma)$ & 0.9999 & 0.9993 \\
\hline Relative standard deviation $(\%)$ & 0.322 & 0.427 \\
\hline Detection limit $(\mu \mathrm{g} \mathrm{mL})$ & 0.014 & 0.021 \\
\hline Determination limit $\left(\mu \mathrm{g} \mathrm{mL}^{-1}\right)$ & 0.041 & 0.064 \\
\hline Composition $(\mathrm{M}: \mathrm{L})$ & $1: 1$ & - \\
\hline Stability constant & $6.951 \times 10^{4}$ & - \\
\hline
\end{tabular}

Table 3: Analysis of Soil samples

\begin{tabular}{|c|c|c|c|c|c|c|c|}
\hline \multirow[t]{2}{*}{ Sample } & \multirow{2}{*}{$\begin{array}{c}\text { Cr added } \\
\text { in } \mu \mathrm{g} \\
\mathrm{mL}^{-1}\end{array}$} & \multicolumn{3}{|c|}{ Proposed method* } & \multicolumn{3}{|c|}{ Reference method } \\
\hline & & $\begin{array}{l}\mathrm{Cr} \text { found } \\
(\mu \mathrm{g} \mathrm{mL}\end{array}$ & $\begin{array}{c}\text { Relative } \\
\text { error }\end{array}$ & $\begin{array}{c}\text { Recovery } \\
(\%)\end{array}$ & $\begin{array}{l}\text { Cr found } \\
\left(\mu \mathrm{g} \mathrm{mL} L^{-}\right.\end{array}$ & $\begin{array}{c}\text { Relative } \\
\text { error }\end{array}$ & $\begin{array}{c}\text { Recovery } \\
(\%)\end{array}$ \\
\hline \multirow{3}{*}{$\begin{array}{c}\text { Soil } \\
\text { Sample }\end{array}$} & 4.00 & 3.98 & +0.5 & 99.5 & 4.01 & -0.25 & 100.25 \\
\hline & 5.00 & 5.01 & -0.2 & 100.2 & 5.01 & -0.2 & 100.2 \\
\hline & 6.00 & 5.99 & +0.17 & 99.8 & 6.02 & -0.33 & 100.3 \\
\hline
\end{tabular}

Table 5: Tolerance limits of diverse ions (in folds)

\begin{tabular}{|l|c|c|}
\hline \multirow{2}{*}{ Diverse Ion } & \multicolumn{2}{|c|}{ Tolerance limits (in folds) } \\
\cline { 2 - 3 } & Zero order & Second derivative \\
\hline $\mathrm{Mo}(\mathrm{VI})$ & 4 & 30 \\
\hline $\mathrm{Cu}(\mathrm{II})$ & 3 & 16 \\
\hline $\mathrm{Mn}(\mathrm{II})$ & 2 & 25 \\
\hline $\mathrm{V}(\mathrm{V})$ & 2 & 20 \\
\hline $\mathrm{Fe}(\mathrm{II})$ & 1 & 9 \\
\hline $\mathrm{Fe}(\mathrm{III})$ & $<1$ & 7 \\
\hline $\mathrm{Pd}(\mathrm{II})$ & $<1$ & 10 \\
\hline $\mathrm{In}(\mathrm{III})$ & $<1$ & 15 \\
\hline
\end{tabular}

Table 6: Analysis of standard steel samples

\begin{tabular}{|l|c|c|c|c|}
\hline \multicolumn{1}{|c|}{ Sample } & $\begin{array}{c}\text { Chromium (VI) } \\
\text { certified value }(\%)\end{array}$ & $\begin{array}{c}\text { Proposed } \\
\text { method* }(\%)\end{array}$ & $\begin{array}{c}\text { Relative } \\
\text { error }\end{array}$ & $\begin{array}{c}\text { Recovery } \\
(\%)\end{array}$ \\
\hline $\begin{array}{l}\text { SAE304 } \\
(\text { Cr 18-Ni 9) }\end{array}$ & 17.98 & 17.96 & +0.11 & 99.88 \\
\hline $\begin{array}{l}\text { SAE321 } \\
(\text { Cr 18-Ni 10-Ti) }\end{array}$ & 17.58 & 17.36 & +1.25 & 98.7 \\
\hline
\end{tabular}

* Average of five determinations 